Int. J. Plant Sci. 158(5):543-551. 1997.

(C) 1997 by The University of Chicago. All rights reserved.

$1058-5893 / 97 / 5805-0006 \$ 03.00$

\title{
CULTURE AND REGENERATION OF PROTOPLASTS FROM SHOOTS OF ASPARAGUS CULTURES
}

\author{
CHEN GUANGYU, ${ }^{*} \uparrow$ A. J. CONNER, ${ }^{1, *} \dagger$ M. C. CHRISTEY, ${ }^{*}$ A. G. FAUTRIER, $\dagger$ AND R. J. FIELD $\dagger$ \\ *New Zealand Institute for Crop \& Food Research Ltd., Private Bag 4704, Christchurch, New Zealand; and \\ $\dagger$ Department of Plant Science, P. O. Box 84, Lincoln University, Canterbury, New Zealand
}

\begin{abstract}
A reliable culture and regeneration protocol has been established for asparagus (Asparagus officinalis L.) protoplasts isolated from shoots of in vitro plants. Studies focused on factors to maximize plating efficiency, colony formation, and plant regeneration. The optimized protocol involved the culture of asparagus protoplasts embedded in agarose beads through a series of defined media. Etiolated shoot cultures were a superior source for protoplasts than green shoot cultures, and growing feeder cells were critical for high plating efficiency and colony formation. In the presence of growing asparagus feeder cells, asparagus protoplasts initiated cell divisions within $2 \mathrm{~d}$ of plating in agarose with plating efficiencies up to $20 \%$. About $80 \%$ of the protoplasts initiating cell divisions developed into colonies of at least 25-30 cells, of which $25 \%$ initiated somatic embryos. Complete plants were regenerated from the embryos at a frequency over $20 \%$. Overall, ca. $0.8 \%$ of the initially isolated protoplasts regenerated into complete plants with this protocol. Plants regenerated from protoplasts have been transferred to soil and maintained phenotypically normal morphology for over 2 yr. Chromosome counts confirmed the diploid status $(2 n=20)$ of plants regenerated by somatic embryogenesis.
\end{abstract}

\section{Introduction}

We have established a protocol for the reliable and efficient isolation of protoplasts from in vitro shoot cultures of asparagus (Chen et al. 1997). Acceptable frequencies of cell division were not achieved using the established procedures for the culture of asparagus protoplasts derived from callus or cell suspensions (Chin et al. 1988; Kong and Chin 1988; Elmer et al. 1989; Hsu et al. 1990; Kunitake and Mii 1990; Dan and Stephens 1991; May and Sink 1995). Therefore, the aim of this study was to establish an appropriate culture system for protoplasts from asparagus shoot cultures. Experiments focused on optimizing factors important for achieving high plating efficiency, colony formation, colony size, and plant regeneration from protoplasts derived from shoots of asparagus cultures. A new protocol for high frequency culture and regeneration of protoplasts from asparagus shoot cultures is defined.

\section{Materials and methods}

\section{Plants}

The asparagus genotypes used were all micropropagated clones under evaluation as parents of hybrid cultivars and included five male clones: CRD 67, CRD 70, 30B (all ex Mary Washington 500), CRD 126 (ex New Jersey 101), and CRD 157 (ex Larac); and three female clones: CRD 74, CRD 75 (both ex Mary Washington 500), and CRD 168 (ex Limbras I). In vitro plant cultures were established as described by Abernethy and Conner (1992) and grown in MS medium (MS salts, vitamins, and sucrose; Murashige and Skoog 1962) plus $200 \mathrm{mg} / \mathrm{L}$ glutamine and $0.1 \mathrm{mg} / \mathrm{L}$ NAA. Following 6 wk growth at $27^{\circ} \mathrm{C}$, either under cool white fluorescent lamps $\left(100 \mu \mathrm{mol} \mathrm{m}^{-2} \mathrm{~s}^{-1} ; 16 \mathrm{~h}\right.$ light: $8 \mathrm{~h}$ darkness daily) to produce green shoots, or in darkness to pro-

${ }^{1}$ Author for correspondence and reprints; fax +64 3 3252074; E-mail connert@crop.cri.nz.

Manuscript received September 1996; revised manuscript received April 1997. duce etiolated shoots, protoplasts were isolated and purified as previously described (Chen et al. 1997).

\section{Protoplast CUlTURE}

LIQUID CULTURE. Freshly isolated and purified protoplasts from green or etiolated shoots were cultured at $10^{5}-$ $10^{6}$ protoplasts $/ \mathrm{mL}$ in either $\mathrm{KMG}$ medium (KM medium as described by Elmer et al. [1989] without mannitol and with $0.6 \mathrm{M}$ glucose) or KMM medium (KM medium as described by Elmer et al. [1989] with $0.395 \mathrm{M}$ mannitol, $0.005 \mathrm{M}$ glucose, and $0.2 \mathrm{M}$ sucrose). One $\mathrm{mL}$ of protoplasts was cultured in darkness at $27^{\circ} \mathrm{C}$ in the single well $(15 \mathrm{~mm}$ diam $\times 18 \mathrm{~mm}$ high, with $3.5-\mathrm{mL}$ well capacity) of flat-bottom 24-well plates. At 5-d intervals, $50 \mu \mathrm{L}$ of the culture medium was replaced with $50 \mu \mathrm{L}$ of fresh KMR medium (KM medium as described by Elmer et al. [1989] with $0.16 \mathrm{M}$ mannitol, $0.005 \mathrm{M}$ glucose, and $0.14 \mathrm{M}$ sucrose) to gradually dilute the osmotic pressure. Different combinations of the plant growth regulators (PGRs) NAA, 2,4-D, kinetin, BA, and zeatin, ranging from 0.1 to $1.5 \mathrm{mg} / \mathrm{L}$, were tested in the liquid medium.

AgAROSE-BEAD CULTURE. Low melting temperature agarose (electrophoresis grade, Gibco BRL Life Technologies) was suspended in culture medium at $2 \%(\mathrm{w} / \mathrm{v})$ and autoclaved at $121^{\circ} \mathrm{C}, 103 \mathrm{kPa}$ for $15 \mathrm{~min}$. Alternatively, the medium was kept in a $70^{\circ} \mathrm{C}$ water bath for a few minutes to melt the agarose, then filter sterilized (Minisart $0.20 \mu \mathrm{m}$, Sartorius). Following autoclaving or filtering, the medium was maintained at $45^{\circ} \mathrm{C}$ in a water bath. Protoplasts were resuspended in filter sterilized liquid culture medium at double the final concentration $\left(1 \times 10^{6}\right.$ protoplasts $/ \mathrm{mL}$ unless otherwise stated). One $\mathrm{mL}$ of agarose medium was then mixed with an equal volume of protoplast suspension and immediately transferred to a petri dish $(6.0 \mathrm{~cm}$ diam $\times 1.5 \mathrm{~cm}$ high $)$ and allowed to gel. The petri dishes were then sealed with Parafilm and incubated in darkness at $27^{\circ} \mathrm{C}$ for $3 \mathrm{wk}$.

\section{FEEDER CELLS}

Asparagus cell suspension cultures were established from friable callus formed at the base of cultured plants. They were maintained by weekly subculture in liquid MS medium supplemented with $400 \mathrm{mg} / \mathrm{L}$ glutamine, and incubated by gyratory shaking $(150 \mathrm{rpm})$ at $27^{\circ} \mathrm{C}$ under cool white fluo- 
rescent lamps $\left(70 \mu \mathrm{mol} \mathrm{m}^{-2} \mathrm{~s}^{-1} ; 16 \mathrm{~h}\right.$ light : $8 \mathrm{~h}$ darkness daily). Four to five days before use as feeder cells, they were transferred to medium with the sucrose concentration increased to $0.24 \mathrm{M}$. When callus was used as feeder cells, it was taken directly from the base of cultured plants. Green or etiolated shoots, cut into ca. 2-cm segments, were used as feeder cells in some experiments. According to experimental design, $0.2-0.3 \mathrm{~g}$ of feeder cells were added to each petri dish of protoplasts embedded in agarose, which was then overlaid with $5 \mathrm{~mL}$ of liquid KMR medium. All feeder cells were of genotype CRD168 unless otherwise stated.

\section{CONDITIONED MEDIUM}

Asparagus cell suspensions were cultured in KMM medium for $1 \mathrm{wk}$. The medium was filtered through $80-\mu \mathrm{m}$ nylon mesh and then a minifilter unit $(0.20 \mu \mathrm{m})$ to eliminate remaining cells. It was then used in the same way as fresh medium during agarose bead culture.

\section{EMBRYO INDUCTION}

After 3-6 wk of culture with feeder cells, agarose-beads with embedded colonies were cut into about $1-2-\mathrm{cm}^{2}$ pieces and each segment was transferred into a new petri dish. Five $\mathrm{mL}$ of $\mathrm{KM}$ or MS medium were added to each dish with PGRs (BA, kinetin, NAA) at varying concentrations from 0.125 to $15 \mathrm{mg} / \mathrm{L}$, with or without feeder cells according to experimental design. Sugar concentration in the medium was tested in the range from $3 \%$ to $12 \%(\mathrm{w} / \mathrm{v})$. Cultures were incubated at $27^{\circ} \mathrm{C}$ under cool white fluorescent lamps (10 $\mu \mathrm{mol} \mathrm{m} \mathrm{m}^{-2} \mathrm{~s}^{-1} ; 16 \mathrm{~h}$ light: $8 \mathrm{~h}$ darkness daily).

\section{Plant REGENERATION}

After a further 4 wk of culture, embryos that developed were immersed in $1 \mathrm{mg} / \mathrm{L} \mathrm{IBA}$ or $1 \mathrm{mg} / \mathrm{L} \mathrm{GA}$ for $10 \mathrm{~min}$, transferred to MS medium supplemented with $200 \mathrm{mg} / \mathrm{L}$ glutamine for plant regeneration, and cultured at $27^{\circ} \mathrm{C}$ under cool white fluorescent lamps $\left(100 \mu \mathrm{mol} \mathrm{m}{ }^{-2} \mathrm{~s}^{-1} ; 16 \mathrm{~h}\right.$ light: $8 \mathrm{~h}$ darkness daily). Regenerated plants were subcultured on R3 medium and transferred to soil as previously described (Abernethy and Conner 1992).

\section{Chromosome counts}

Chromosome counts followed the procedures of Morgan et al. (1995) with minor modifications. Healthy root tips from plants in culture or root tips that protruded through the bottom of the polythene greenhouse bags were excised, placed into distilled water on ice for $24 \mathrm{~h}$, fixed in chloroform : ethanol : glacial acetic acid $(6: 3: 1)$, and kept at room temperature for at least $1 \mathrm{~h}$. Fixative was removed and replaced with $60^{\circ} \mathrm{C} 1 \mathrm{~N} \mathrm{HCl}$ for ca. $10 \mathrm{~min}$. Roots were stained with Feulgens stain, softened with $3 \%$ pectinase, and then transferred to $45 \%$ acetic acid. Root tips were squashed in Aceto Carmine and chromosomes observed at $1000 \times$ magnification. A minimum of four roots per plant and 5-10 mitotic spreads per root were analyzed.

\section{DATA COLLECTION AND STATISTICAL ANALYSIS}

Plating efficiency (PE), defined as the percentage of protoplasts showing a first cell division, was determined after three weeks of culture. Five to 15 random microscopic fields were examined depending on initial plating density in order to count at least 500-1000 cells. Values were averaged to represent the mean of each replicate. Colony formation, defined as the percentage of dividing protoplast-derived cells passing through repeated cell divisions and resulting in colonies of least 25-30 cells, and colony size were determined four weeks after plating. The diameter of cell colonies was determined using image analysis as previously described (Chen et al. 1997), with an average of 100 colonies randomly chosen from the culture. All experiments involved a completely randomized design with three replicates. Data were subjected to angular (angle $=\arcsin (\%)^{0.5}$ ) or $\log _{10}$ transformation when necessary (Snedecor and Cochran 1969), and treatments were compared using analysis of variance.

\section{Results}

\section{PRELIMINARY EXPERIMENTS}

Cell divisions were rarely observed for either green or etiolated protoplasts in liquid KMM medium. A maximum of eight dividing cells per $\mathrm{mL}$ were observed over all densities ranging from $10^{5}$ to $10^{6}$ protoplasts/mL. Only a few cells in liquid medium passed through a second division. One week after culture initiation, these cells usually aggregated into clumps, and cell division stopped within $2 \mathrm{wk}$, irrespective of plant growth regulators used (single applications and combinations of NAA, 2, 4-D, kinetin, BA and zeatin ranging from 0.1 to $1.5 \mathrm{mg} / \mathrm{L}$ ). The most promising response appeared to result from the use of $0.5 \mathrm{mg} / \mathrm{L}$ BA combined with $1 \mathrm{mg} / \mathrm{L}$ 2,4-D. Therefore, this combination was used in subsequent experiments. When cultured in agarose beads in the presence of feeder cells, asparagus protoplasts from etiolated shoots (fig. 1A) started to divide (fig. $1 B$ ) and form cell colonies (fig. $1 C$ ) within several days. In contrast, protoplasts isolated from green shoots exhibited only cell expansion or budding and no cell division. Protoplasts isolated from etiolated shoots and agarosebead cultures were used in all subsequent experiments.

\section{AUTOCLAVED COMPARED WITH FILTER STERILIZED} MEDIUM

Two independent experiments using CRD 67 and CRD 168 protoplasts resulted in higher PE in filter sterilized medium compared with autoclaved medium. Analysis of variance established a highly significant difference between the two treatments $(P<0.001)$ for both genotypes (fig. 2). Consequently, filter sterilized medium was used in all following experiments.

\section{GLUCOSE COMPARED WITH MANNITOL AS OSMOTICUM}

Three independent experiments were conducted using CRD 67 or CRD 168 protoplasts embedded in agarose beads with either glucose (KMG medium) or mannitol (KMM medium) as osmoticum. Analysis of variance established a significant difference in PE between the two treatments $(P<0.05)$ for all three experiments (fig. 3). Therefore, KMM medium was used in all subsequent experiments.

\section{INFLUENCE OF FEEDER CELLS ON AGAROSE-BEAD CULTURE}

No cell division was observed in agarose-embedded protoplasts in the absence of feeder cells, irrespective 
of whether fresh medium or conditioned medium was used. Protoplasts cultured in fresh medium did not show any response during the culture period. In contrast, protoplasts cultured in conditioned medium showed a slight swelling and the development of a darker coloration. Cells showing this response were those in which division could be induced by the feeder cells.

Friable cell suspensions, callus, and in vitro shoots of asparagus were all highly effective as feeder cells for inducing cell division of protoplasts from genotypes 30B and CRD168 (fig. 4). Analysis of variance established a significant difference between the feeder treatments and the genotypes (both $P<0.001$ ) with significant interaction $(P<0.05)$. Cell suspensions, two to three subcultures after initiation, were the best type of feeder cells. These cultures contained highly friable cells with irregular shape and induced cell division and subsequent colony formation (fig. $1 C$ ) from asparagus protoplasts of all genotypes tested (CRD 67, CRD 70, CRD 74, CRD 75, CRD 126, CRD 157, CRD 168, and 30B). When the cell suspension cultures were maintained for longer than four to five subcultures, they developed into aggregates of small compact cells, and their ability to act as feeder cells gradually diminished.

Callus from the base of shoot cultures also had a positive feeder cell effect on protoplasts from etiolated shoots. The feeder effect of callus was intermediate between cell suspension and shoots (e.g., fig. 4) and supported cell division in isolated protoplasts from all genotypes tested (CRD 74, CRD 75, CRD 126, CRD 168 , and 30B). Both green and etiolated shoots induced cell division of protoplasts without significant difference between them (data not shown). However, shoots were less effective than cell suspension cultures and callus as feeder cells for asparagus protoplasts.

Cell suspensions from different genotypes (CRD 70, CRD 74, CRD 75, CRD 168, and 30B) all had feeding ability. A direct comparison of three genotypes (CRD $168,30 B$, and CRD 70) to promote PE of CRD 168 protoplasts established a highly significant difference $(P<0.001)$ between the sources of feeder cells using analysis of variance (fig. 5). The higher capacity of 30B and CRD 168 cell suspensions to induce higher PE's probably reflects the high callus initiation and growth rate in these two genotypes. A cell suspension of CRD 168 was used as a source of feeder cells in all subsequent experiments.

\section{PLANT GROWTH REGULATORS}

Combinations of PGRs commonly used for asparagus callus culture and protoplasts derived from callus were tested for their ability to induce cell division of protoplasts derived from etiolated shoots. Two independent experiments were performed with analysis of variance establishing a significant difference between treatments and between the two experiments (both $P$ $<0.001)$ with no significant interaction $(P>0.05)$ (fig. 6). Combination V (0.5 mg/L kinetin, $0.5 \mathrm{mg} / \mathrm{L}$ 2 , 4-D and $0.5 \mathrm{mg} / \mathrm{L} \mathrm{NAA}$ ) resulted in a significantly higher PE in both experiments (fig. 6). Analysis of variance established a highly significant difference between the PGR treatments $(P<0.001)$ for colony formation, as well as a significant difference $(P<0.05)$ for colony size (fig. 7). Since the PGRs of combination $\mathrm{V}$ also resulted in a high frequency of colony formation and a larger colony size, they were therefore adopted for all later experiments.

\section{Plating EFFICIENCY AT DIFFERENT DENSITIES}

The initial density at which protoplasts were plated had a significant influence on PE. In three separate experiments with CRD 168, analysis of variance confirmed a significant difference between the plating densities (all $P<0.01$ ) in each experiment, with PE increasing with higher plating density (fig. 8). Generally, the PE was over $12 \%$ when the plating density was greater than $2 \times 10^{6}$ protoplasts $/ \mathrm{mL}$. Although this was consistent in all experiments, the overall PE's were higher in some experiments. Lower plating densities not only resulted in lower PE, but also in lower frequencies of colony formation. When plating density was ca. $10^{4}$ protoplasts $/ \mathrm{mL}$, colony formation was very low (data not shown). Therefore, plating densities above $1 \times 10^{6}$ protoplasts $/ \mathrm{mL}$ were used in later experiments.

\section{GENOTYPE RESPONSE}

In three separate experiments, CRD 67, CRD 168, and 30B showed high PE's, whereas CRD 74 and CRD 126 responded poorly to protoplast culture (table 1 ). CRD 157 was the poorest performing genotype with PE routinely less than 3\% (data not shown).

\section{CONTINUED DEVELOPMENT OF CELL COLONIES}

Protoplasts cultured in agarose-beads with feeder cells for 3-6 wk usually yielded colonies $0.5-1 \mathrm{~mm}$ in diam (figs $1 C$ and $1 D$ ). At this stage, the agarose-beads were cut into small pieces $\left(1-2 \mathrm{~cm}^{2}\right)$ and then transferred to a range of media for regeneration. Experiments with genotypes 30B, CRD 67, and CRD 168 established that feeder cells were still necessary to maintain colony growth even when the KMR medium was supplemented with a range of PGRs. Kinetin had greater effect than BA on colony formation and colony size and also induced a low frequency of plant regeneration via organogenesis in some instances. Although the MS medium with kinetin at low concentrations also resulted in cell death, the colonies survived much longer without feeder cells than in KMR medium. More importantly, when NAA was combined with low kinetin $(0.2 \mathrm{mg} / \mathrm{L})$ in MS medium, continuous growth of colonies was observed without feeder cells. The optimized level was $0.2 \mathrm{mg} / \mathrm{L}$ kinetin with $10 \mathrm{mg} / \mathrm{L}$ NAA, and this medium was used in subsequent experiments.

\section{EMBRYO INDUCTION AND GERMINATION}

With increasing sucrose concentration, colonies became more compact with a higher capacity for embryo development. The highest number of embryos 
A

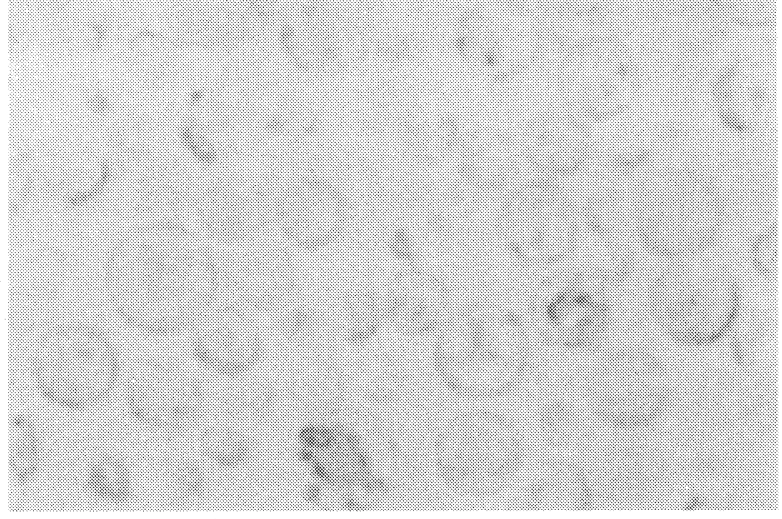

C
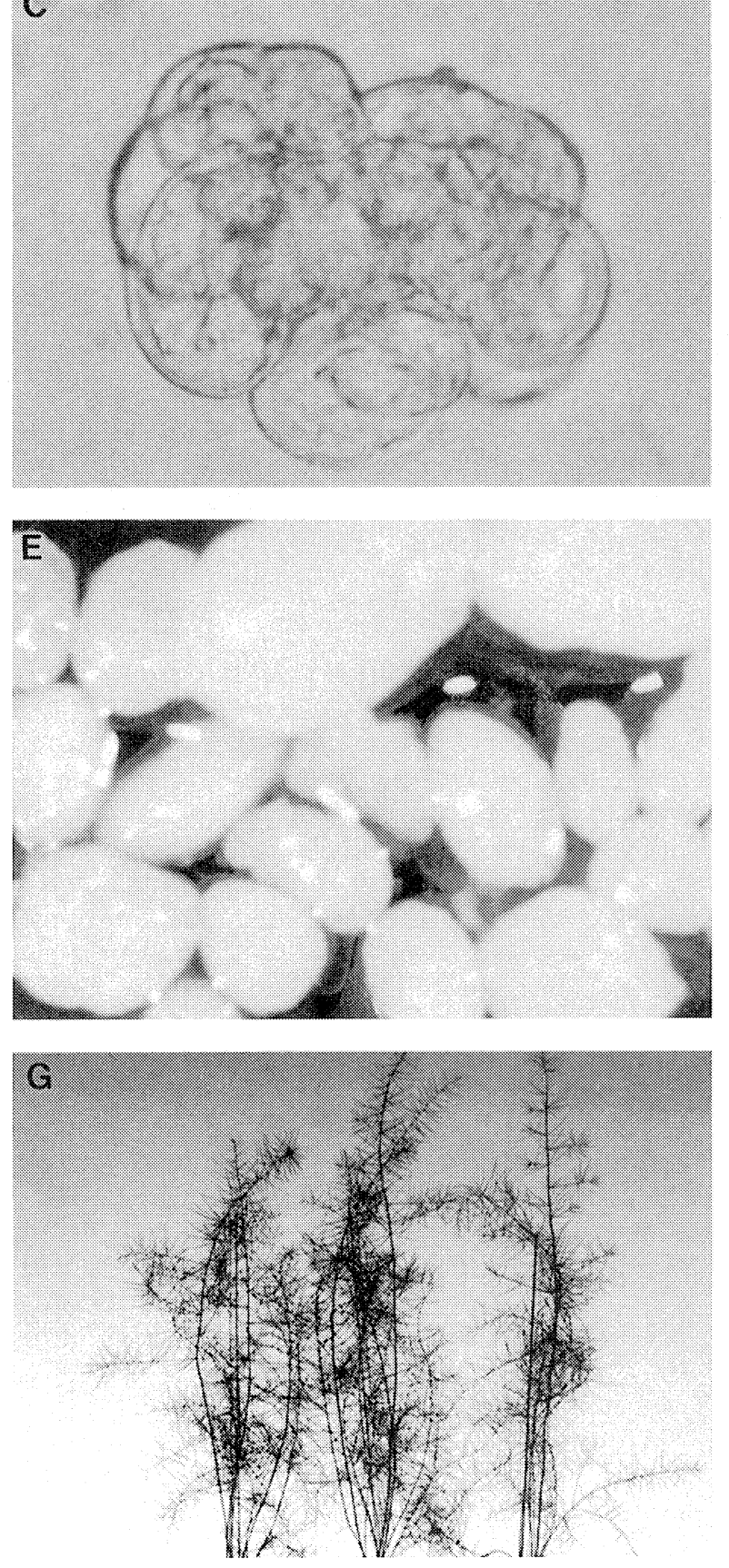

B
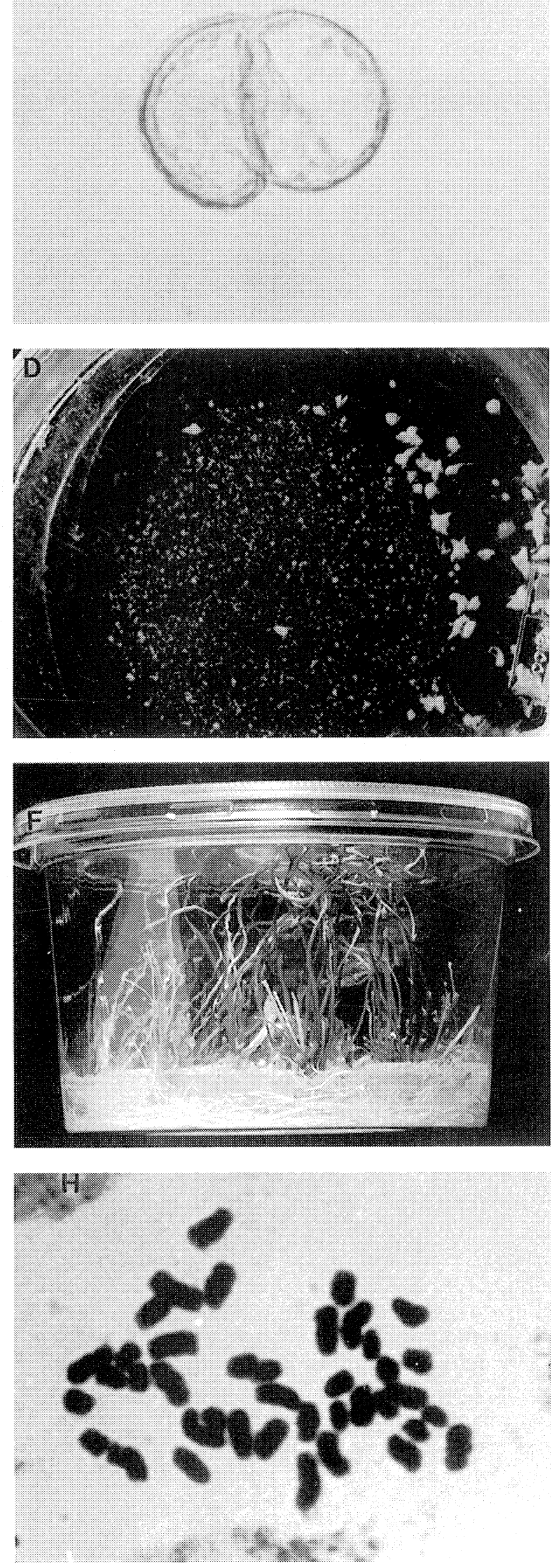


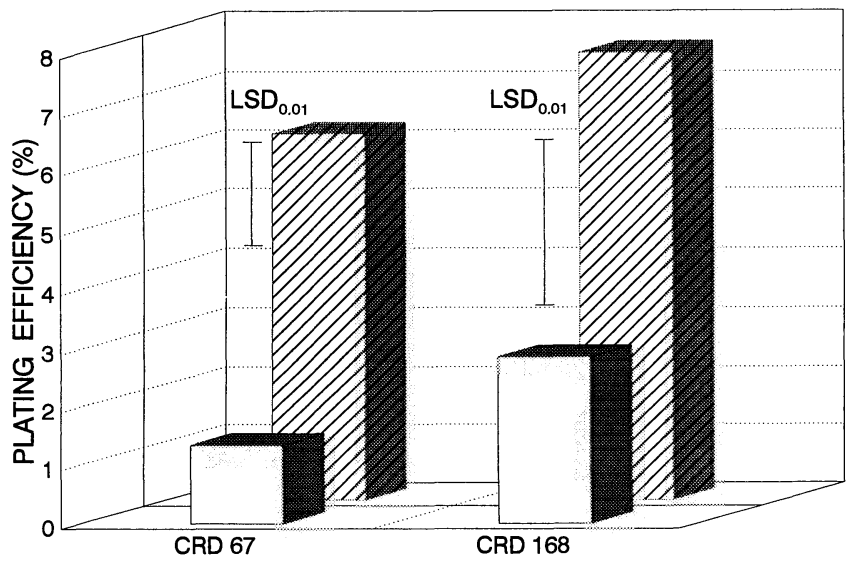

Fig. 2 Plating efficiency of asparagus protoplasts cultured in either autoclaved medium (front bar) or filter sterilized medium (back bar).

was observed in MS medium containing $0.2 \mathrm{mg} / \mathrm{L}$ kinetin, $10 \mathrm{mg} / \mathrm{L}$ NAA, and $12 \%$ sucrose. After $4 \mathrm{wk}$ culture on this embryo induction medium, most embryos usually had a globular form, although some had developed into a torpedo form (fig. $1 E$ ). For asparagus genotypes that responded well to culture of protoplasts (CRD 67, 30B, and CRD 168), ca. 25\% of protoplast-derived cell colonies routinely developed embryos. The immersion of these embryos in either $1 \mathrm{mg} / \mathrm{L}$ IBA or $1 \mathrm{mg} / \mathrm{L} \mathrm{GA}_{3}$ for $10 \mathrm{~min}$, followed by their transfer to MS medium without PGRs, resulted in a significantly higher frequency of germination than the control $(P<0.05$; fig. 9). The resulting plants (fig. $1 F$ ) have been successfully transferred to soil and grown under greenhouse conditions for $3 \mathrm{yr}$. All plants maintained a phenotypically normal appearance during this time (fig. $1 G$ ).

\section{Chromosome NumBer OF REgENERATED PLANTS}

The normal chromosome number $(2 n=20)$ was counted in all nine plants examined that resulted from somatic embryogenesis. In contrast, the chromosome number of two plants derived from organogenesis had doubled to the tetraploid level $(2 \mathrm{n}=40$; fig. $1 H)$.

\section{Discussion}

We report the successful culture and plant regeneration from protoplasts derived from in vitro asparagus shoot cultures. The final optimized protocol is summarized in table 2. Published protocols for asparagus protoplast culture that used callus or cell suspension cultures as the source tissue (Chin et al. 1988; Kong

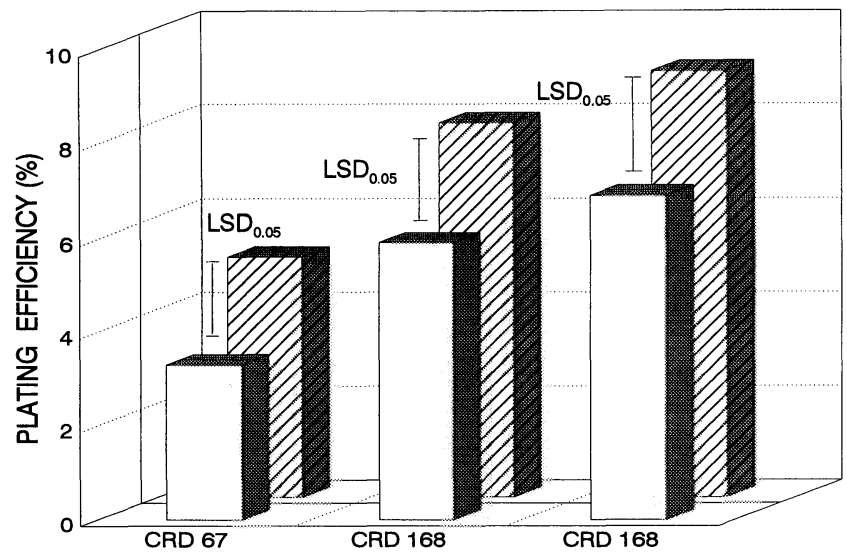

Fig. 3 Plating efficiency of asparagus protoplasts with either glucose (front bars) or mannitol (back bars) as osmoticum in the culture medium.

and Chin 1988; Elmer et al. 1989; Hsu et al. 1990; Kunitake and Mii 1990; Dan and Stephens 1991; May and Sink 1995) were ineffective for the culture and regeneration of shoot-derived protoplasts in the present study. This may result from genotype differences and/or because protoplasts from in vitro shoots are more difficult to regenerate. Therefore, the establishment of a new system for the culture and regeneration of asparagus protoplasts from in vitro shoot cultures was necessary. Compared with other reports on asparagus protoplast culture, the protocol reported in this study is highly efficient. Depending on asparagus genotype, PE up to $20.3 \%$ was achieved, which is higher than most previous reports (15\%, Bui-Dang-Ha and Mackenzie 1973; 10\%, Chin et al. 1988; 10\%, Kong and Chin 1988; 6.5\%-7.3\%, Elmer et al. 1989; not stated, Hsu et al. 1990; 7.2\%, Kunitake and Mii 1990; 19.1\%, Dan and Stephens 1991). The frequency of colony formation from dividing protoplasts was $80 \%$, which is approximately the same as that reported by Dan and Stephens (1991), whereas in all other publications this information is not reported.

Although other studies have recovered plants from asparagus protoplasts, the frequency of regeneration is often not mentioned (Bui-Dang-Ha and Mackenzie 1973; Bui-Dang-Ha et al. 1975; Chin et al. 1988; Kong and Chin 1988; Hsu et al. 1990). Shoot organogenesis from $35 \%$ of cell colonies has been reported by Elmer et al. (1989) without stating the frequency of complete plant regeneration, and by Dan and Stephens (1991) with $79 \%$ of cell colonies regenerating complete plants. Somatic embryogenesis from asparagus proto-

$\leftarrow$

Fig. I The culture and regeneration to plants of asparagus protoplasts from in vitro etiolated shoots of genotype CRD 168 . A, Freshly isolated protoplasts from etiolated shoots $(\times 575)$. B. First cell division of a protoplast-derived cell after $2 \mathrm{~d}$ culture in the presence of cell suspension feeder cells $(\times 1150)$. $C$, Small cell colony after four to five cell divisions following $10 \mathrm{~d}$ culture in the presence of cell suspension feeder cells $(\times 425) . D$, Protoplast-derived cell colonies embedded in agarose-beads in the presence of feeder cells (feeder cells have developed into embryogenic structures and are mainly visible to the right of the photograph) $(\times 1.9)$. $E$, Regenerated somatic embryos ( $\times 10)$. $F$, Plants regenerated from protoplasts by somatic embryogenesis $(\times 0.9)$. $G$, Protoplast-derived plants established in a greenhouse $(\times 0.05)$. $H$, Chromosomes of a tetraploid plant $(2 n=4 x=40)$ regenerated by organogenesis $(\times 3850)$. 


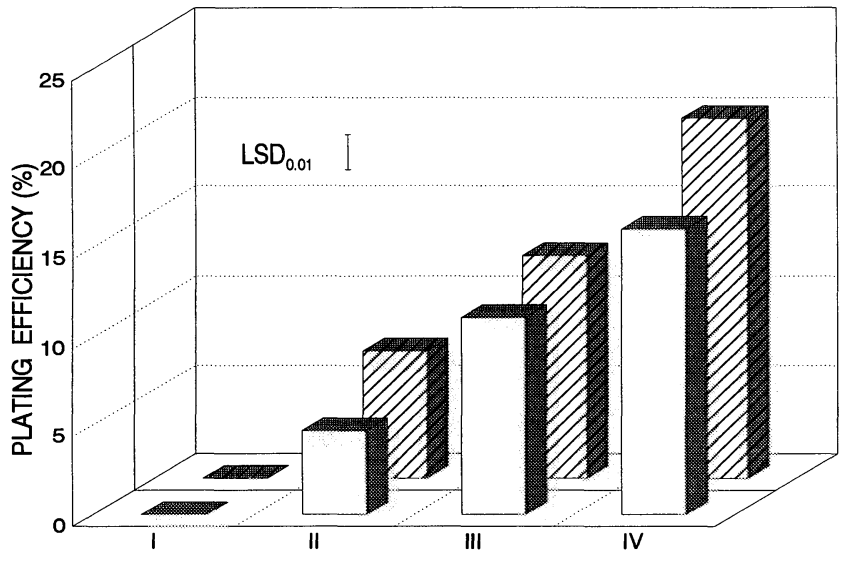

Fig. 4 Plating efficiency of asparagus protoplasts from genotypes 30B (front bars) and CRD 168 (back bars) in response to different sources of asparagus feeder cells. Protoplasts plated at a density of $5 \times 10^{6}$ protoplasts $/ \mathrm{mL}$ were cultured either without feeder cells (control, I) or with green shoots (II), callus (III) or cell suspensions (IV) as feeder cells.

plasts has been reported at frequencies up to $40 \%$ (Kunitake and Mii 1990; May and Sink 1995). Both forms of regeneration were also observed in this study with somatic embryogenesis occurring at a higher frequency ( $25 \%$ of cell colonies). Plants arising via organogenesis were tetraploid, whereas those arising by embryogenesis retained their diploid status. This contradicts the results of Odake et al. (1993), who regenerated tetraploid asparagus plants via somatic embryogenesis. However, their source tissue was callus, so this result is not unexpected.

PE often showed a large variation between experiments, which may reflect the condition of plant cells used for experimentation, either as sources of protoplasts or as feeder cells. Feeder cells are well known to facilitate the recovery of viable cells plated at very low densities (Horsch and Jones 1980). In this study, the quality of asparagus feeder cells was critical for the successful culture of asparagus protoplasts, with vigorously growing suspension cultures of friable cells

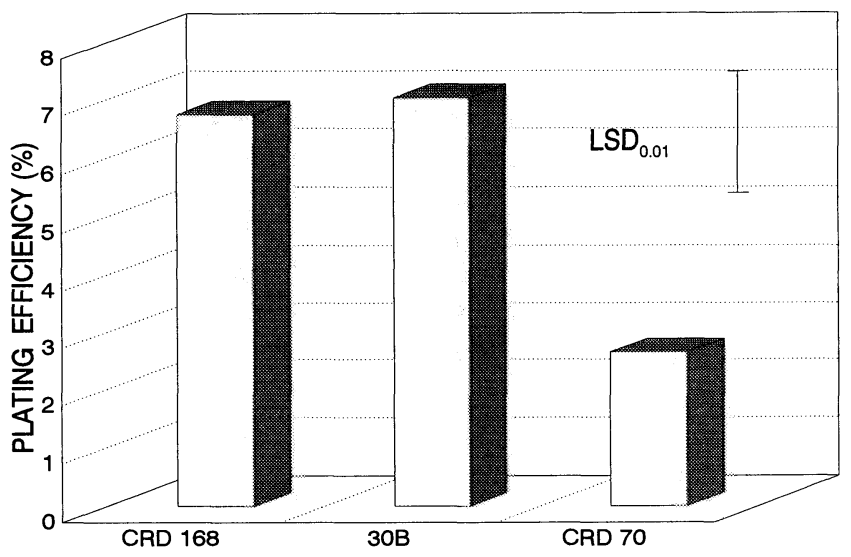

Fig. 5 Plating efficiency of asparagus protoplasts from CRD 168 using different asparagus genotypes (CRD 168, 30B, and CRD 70) as the source of feeder cell suspensions.

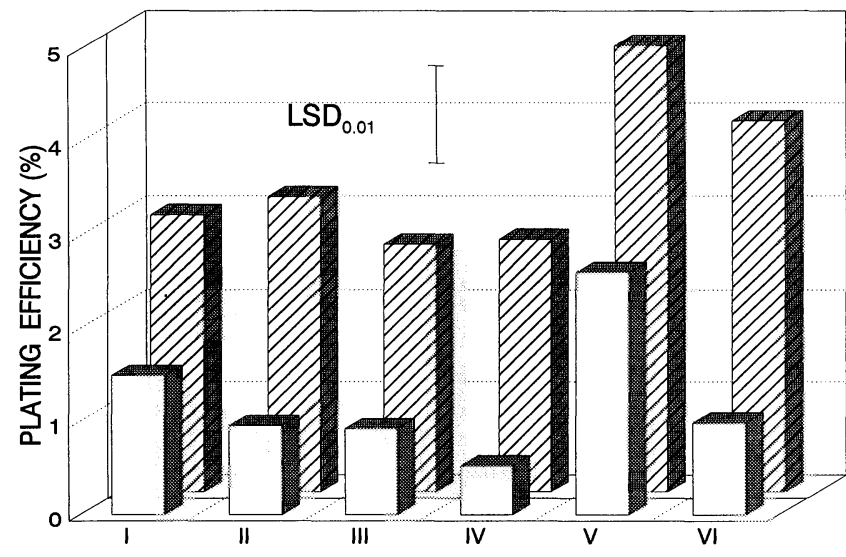

Fig. 6 Plating efficiency of asparagus protoplasts from CRD 168 in two independent experiments (front bars and back bars, respectively) with a range of plant growth regulators. The base KMM medium was supplemented with either I $(0.5 \mathrm{mg} / \mathrm{L} \mathrm{BA}+1 \mathrm{mg} / \mathrm{L}$ 2,4-D); II (1 mg/L BA + $1 \mathrm{mg} / \mathrm{L} \mathrm{2,4-D);} \mathrm{III} \mathrm{(} 1 \mathrm{mg} / \mathrm{L} \mathrm{BA}+1.5 \mathrm{mg} / \mathrm{L}$ 2,4-D); IV (1 mg/L kinetin $+1 \mathrm{mg} / \mathrm{L} 2,4-\mathrm{D}) ; \mathrm{V}(0.5 \mathrm{mg} / \mathrm{L}$ kinetin $+0.5 \mathrm{mg} / \mathrm{L} 2,4-\mathrm{D}+0.5 \mathrm{mg} / \mathrm{L} \mathrm{NAA}) ;$ or $\mathrm{VI}(1 \mathrm{mg} / \mathrm{L} \mathrm{BA}+0.5$ $\mathrm{mg} / \mathrm{L} 2,4-\mathrm{D}+0.5 \mathrm{mg} / \mathrm{L} \mathrm{NAA})$.

with irregular shape being important. All the asparagus genotypes tested as feeder cells in this study supported the growth and cell division of asparagus protoplasts, although there existed significant differences in their feeding strength. In particular, genotypes that readily initiate callus were the more effective genotypes as feeder cells.

Glucose was an important metabolite for cell growth and protoplasts isolated from asparagus callus with glucose as the osmoticum grew much faster than when mannitol or sorbitol were used (Kong and Chin 1988). However, in this study the use of mannitol as an osmoticum for shoot-derived asparagus protoplasts resulted in a higher PE, although the use of glucose as an osmoticum was preferable for the enzymatic release of the protoplasts during their isolation (Chen et al. 1997). High glucose concentrations are known to repress the synthesis of many enzymes involved in the

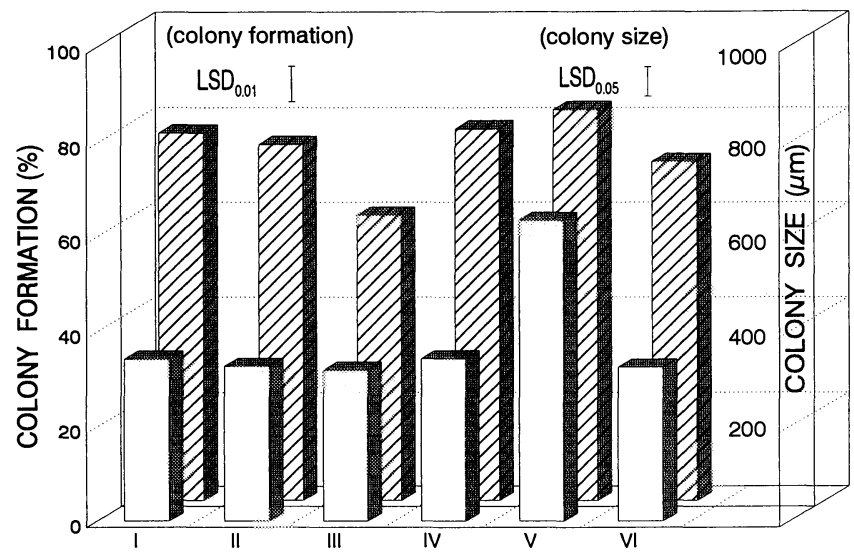

Fig. 7 Colony size (front bars) and colony formation (back bars) from asparagus protoplasts of CRD168 cultured in medium with different combinations of plant growth regulators as defined in fig. 6 . 


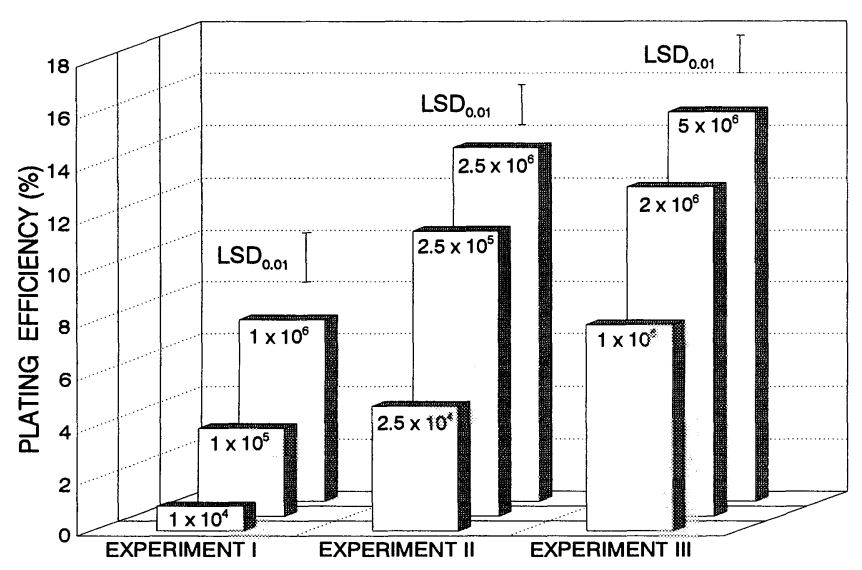

Fig. 8 Plating efficiency of asparagus genotype CRD 168 at different plating densities in three independent experiments. The figure at the top of each bar represents plating density (number of protoplasts $/ \mathrm{mL})$.

production of metabolites in microbial systems (Magasanik 1961; Beck and von Meyenburg 1968). A similar regulatory mechanism has also been observed in asparagus cells cultured in heterotrophic conditions (Tassi et al. 1984). In our culture system, the protoplasts were cultured under heterotrophic conditions, with the concentration of glucose used as osmoticum $(0.6 \mathrm{M})$ well above that known to induce glucose catabolite-repression (Tassi et al. 1984). This provides a metabolic basis to explain why high glucose in asparagus protoplast culture medium results in low PE.

KM medium has been widely used for protoplast culture of many species, including asparagus (Elmer et al. 1989; Dan and Stephens 1991). In this study, it was also beneficial for the isolation (Chen et al. 1997) and culture of protoplasts from asparagus shoots. However, when the cell colonies reached about 0.5-1 $\mathrm{mm}$ diam, MS medium was preferable over KM medium. This may reflect the different nutritional requirement of cells at different developmental stages, be-

Table 1

PROTOPLAST PLATING EFFICIENCY OF DIFFERENT ASPARAGUS GENOTYPES

\begin{tabular}{|c|c|c|c|}
\hline Genotype & $\begin{array}{c}\text { Experiment I } \\
\left(\mathrm{IPD}^{\mathrm{a}}=6 \times 10^{6}\right)\end{array}$ & $\begin{array}{c}\text { Experiment II } \\
\left(\mathrm{IPD}^{\mathrm{a}}=5 \times 10^{6}\right)\end{array}$ & $\begin{array}{c}\text { Experiment III } \\
\left(\mathrm{IPD}^{\mathrm{a}}=1 \times 10^{6}\right)\end{array}$ \\
\hline CRD 168 & 16.5 & 20.3 & 12.0 \\
\hline CRD 67 & 18.6 & $\ldots$ & $\ldots$ \\
\hline CRD $74 \ldots \ldots$ & 8.4 & $\ldots$ & 5.3 \\
\hline CRD $75 \ldots \ldots$ & 14.8 & $\ldots$ & $\ldots$ \\
\hline CRD $70 \ldots \ldots$ & $\cdots$ & 12.5 & $\cdots$ \\
\hline 30B $\ldots \ldots \ldots$ & $\ldots$ & 16.0 & $\ldots$ \\
\hline CRD $126 \ldots$ & $\ldots$ & $\ldots$ & 6.4 \\
\hline $\operatorname{LSD}_{0.01} \ldots \ldots$ & 2.2 & 3.1 & 1.7 \\
\hline
\end{tabular}

Note. Analysis of variance established a significant difference between genotypes for each of these experiments (all $P<0.001$ ). Ellipsis points $(\cdots)$ represent a genotype not included in the experiment.

${ }^{a}$ Initial plating density (protoplasts/mL).

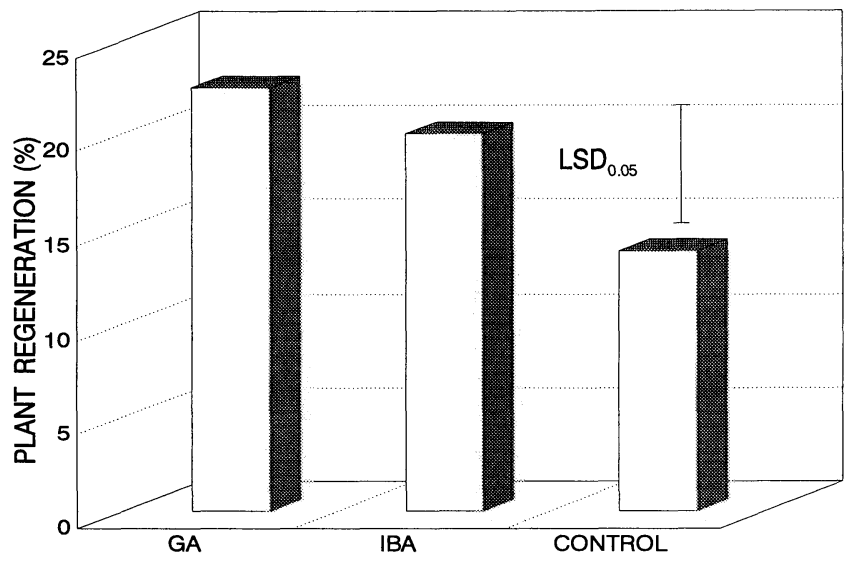

Fig. 9 Plant regeneration from somatic embryos originating from asparagus protoplasts following treatment with $1 \mathrm{mg} / \mathrm{L} \mathrm{IBA}$ or $1 \mathrm{mg} / \mathrm{L}$ $\mathrm{GA}_{3}$. Each bar represents the mean of four replicates of 20 embryos.

cause the composition of $\mathrm{KM}$ medium differs greatly from MS medium, especially with respect to complex organic supplements that may help support initial growth of protoplasts.

Table 2

PROTOCOL FOR CULTURE AND REGENERATION OF PROTOPLASTS FROM SHOOTS OF IN VITRO ASPARAGUS CULTURES

1. Pellet protoplasts by centrifugation at $650 \mathrm{~g}$ for $10 \mathrm{~min}$ and resuspend, at double the intended concentration $\left(>1 \times 10^{6}\right.$ protoplasts $/ \mathrm{mL}$ ), in filter sterilized liquid KMM medium (KM medium as defined by Elmer et al. [1989] but with $0.395 \mathrm{M}$ mannitol, $0.005 \mathrm{M}$ glucose, and $0.2 \mathrm{M}$ sucrose), supplemented with $0.5 \mathrm{mg} / \mathrm{L}$ kinetin, $0.5 \mathrm{mg} / \mathrm{L} 2,4-\mathrm{D}$ and $0.5 \mathrm{mg} / \mathrm{L}$ NAA.

2. Melt $2 \%(\mathrm{w} / \mathrm{v}) \mathrm{LMT}$ agarose in $1 \mathrm{~mL} \mathrm{KMM}$ medium at $70^{\circ} \mathrm{C}$, filter sterilize through a minifilter unit (Minisart $0.20 \mu \mathrm{m}$, Sartorius), then maintain in a water bath at $45^{\circ} \mathrm{C}$.

3. Mix $1 \mathrm{~mL}$ of the melted agarose with $1 \mathrm{~mL}$ of protoplast suspension and quickly transfer to a petri dish $(60 \mathrm{~mm}$ diam $\times 15$ $\mathrm{mm}$ high) before the agarose solidifies.

4. After the protoplasts are embedded in the solidified agarose, add $0.2-0.3 \mathrm{~g}$ of asparagus cell suspension feeder cells and $5 \mathrm{~mL}$ of liquid KMR medium (KM medium as defined by Elmer et al. [1989] but with $0.16 \mathrm{M}$ mannitol, $0.005 \mathrm{M}$ glucose, and 0.14 M sucrose).

5. Seal the petri dishes with Parafilm and incubate in darkness at $27^{\circ} \mathrm{C}$ for 3-4 wk.

6. Remove the feeder cells and KMR medium when the protoplastderived cell colonies are about $0.5-1 \mathrm{~mm}$ diam.

7. Slice the agarose beads with embedded cell colonies into 1-2$\mathrm{cm}^{2}$ segments, add $5 \mathrm{~mL}$ of liquid MS medium (MS salts and vitamins [Murashige and Skoog 1962]), supplemented with 0.2 $\mathrm{mg} / \mathrm{L}$ kinetin, $10 \mathrm{mg} / \mathrm{L} \mathrm{NAA}$, and $12 \%$ sucrose.

8. Incubate the cultures for $4-5$ wk at $27^{\circ} \mathrm{C}$ under low light intensity provided by cool white fluorescent lamps $\left(10 \mu \mathrm{mol} \mathrm{m}^{-2} \mathrm{~s}^{-1}\right.$; $16 \mathrm{~h}$ light : $8 \mathrm{~h}$ darkness photoperiod) to induce embryos.

9. Immerse developed embryos (1 mm long or diam) in $1 \mathrm{mg} / \mathrm{L}$ $\mathrm{GA}_{3}$ (filter sterilized) for $10 \mathrm{~min}$, transfer to MS medium (without plant growth regulators) solidified with $0.7 \%$ agar, and culture at $27^{\circ} \mathrm{C}$ under cool white fluorescent lamps $\left(10 \mu \mathrm{mol} \mathrm{m} \mathrm{m}^{-2}\right.$ $\mathrm{s}^{-1} ; 16 \mathrm{~h}$ light : $8 \mathrm{~h}$ darkness photoperiod).

10. Regenerated plants are transferred to R6 medium (MS salts and vitamins, $200 \mathrm{mg} / \mathrm{L}$ L-glutamine, $0.1 \mathrm{mg} / \mathrm{L} \mathrm{NAA}, 0.1 \mathrm{mg} / \mathrm{L}$ ancymidol, $6 \%$ sucrose, and $0.7 \%$ agar) to induce storage root development, then transplanted to soil in a greenhouse (Abernethy and Conner 1992). 
The beneficial effect of NAA or IAA on embryo induction was also reported in asparagus (Bui-Dang-Ha et al. 1975). High NAA concentration $(5-10 \mathrm{mg} / \mathrm{L})$ was essential for the development of protoplast-derived cell colonies and the subsequent induction of somatic embryos in this study. This is similar to the result reported by Levi and Sink (1991), who found that MS medium supplemented with $10 \mathrm{mg} / \mathrm{L}$ NAA enhanced embryogenesis and germination to normal plantlets. High sucrose concentration was the most favorable for embryo induction in asparagus (Levi and Sink 1990, 1992). Similarly, the highest sucrose concentration $(12 \%)$ resulted in the highest number of embryos in this study. The high osmotic potential induced by the high carbohydrate level is known to promote embryonic differentiation (Granatek and Cockerline 1978) but may inhibit subsequent embryo conversion into complete plants ( $\mathrm{Lu}$ et al. 1983). Therefore, it is necessary to transfer embryos to a low sugar concentration for germination. Kunitake and Mii (1990) germinated asparagus somatic embryos by sugar starvation or immersing embryos in water for a week. Without this treatment, germination of embryos was rare. In our study, germination of somatic embryos occurred following their transfer from $12 \%$ sucrose to MS basal medium with $3 \%$ sucrose after immersing them in 1 $\mathrm{mg} / \mathrm{L} \mathrm{IBA}$ or $1 \mathrm{mg} / \mathrm{L} \mathrm{GA}_{3}$ for $10 \mathrm{~min}$. This IBA or $\mathrm{GA}_{3}$ treatment was beneficial for germination of somatic embryos, which was in accordance with a previous report (Kunitake and Mii 1990).

Overall, ca. $0.8 \%$ of the original protoplasts isolated from etiolated shoot cultures could be regenerated into complete plants $(20 \% \mathrm{PE} \times 80 \%$ colony formation $\times$
$25 \%$ embryo induction $\times 20 \%$ plant development). This high frequency of success was achieved using in vitro shoot cultures as the source material and was similar to the more efficient reports using callus or cell suspensions as the source tissue (Dan and Stephens 1991; May and Sink 1995). The genotypic effects on asparagus protoplast culture and regeneration confirmed the results of May and Sink (1995) and were achieved using a range of elite asparagus genotypes. The key advantage of using in vitro shoot cultures as the source tissue is that protoplasts are isolated from differentiated cells of uniform genetic status. The disadvantage of using undifferentiated callus tissue is the high incidence of somaclonal variation observed among callus-derived asparagus plants (Malnassy and Ellison 1970; Hirate et al. 1995; Kunitake 1995). Cytofluorometric analysis has established that undifferentiated cell suspension cultures have highly variable ploidy levels compared with differentiated tissue from shoots and roots (Galli et al. 1988). The culture system developed in this study will be very useful for genetic manipulation of asparagus using somatic approaches such as cell selection, cell fusion and more importantly, genetic transformation via direct gene transfer.

\section{Acknowledgments}

We thank Andrew Wallace for advice on statistical analysis, Robert Lamberts for photography, and Peter Falloon for providing the initial plant material. This work was supported by a Lincoln University doctoral scholarship to Chen Guangyu and the New Zealand Institute for Crop \& Food Research Ltd.

\section{Literature cifed}

Abernethy DJ, AJ Conner 1992 Laboratory guide for the micropropagation of asparagus. Crop \& Food Research Report, no. 1. Christchurch, New Zealand.

Beck C, KK von Meyenburg 1968 Enzyme pattern and aerobic growth of Saccharomyces cerevisiae under various degrees of glucose limitation. J Bacteriol 96:479-486.

Bui-Dang-Ha D, IA Mackenzie 1973 The division of protoplasts from Asparagus officinalis L. and their growth and differentiation. Protoplasma 78:215-221.

Bui-Dang-Ha D, B Norreel, A Masset 1975 Regeneration of Asparagus officinalis $\mathrm{L}$. through callus cultures derived from protoplasts. J Exp Bot 26:263-270.

Chen GY, AJ Conner, MC Christey, AG Fautrier, RJ Field 1997 Protoplast isolation from shoots of in vitro asparagus cultures. Int J Plant Sci 158:537-542.

Chin CK, Y Kong, H Pedersen 1988 Culture of droplets containing asparagus cells and protoplasts on polypropylene membrane. Plant Cell Tissue Organ Cult 15:59-65.

Dan YH, CT Stephens 1991 Studies of protoplast culture types and plant regeneration from callus-derived protoplasts of Asparagus officinalis L. cv. Lucullus 234. Plant Cell Tissue Organ Cult 27: 321-331.

Elmer WH, T Ball, M Volokita, CT Stephens, KC Sink 1989 Plant regeneration from callus-derived protoplasts of asparagus. J Am Soc Hortic Sci 114:1019-1024.

Galli MG, M Bracale, A Falavigna, C Soave 1988 Sexual differentiation in Asparagus officinalis L. I. DNA characterization and mRNA activities in male and female flowers. Sex Plant Reprod 1:202-207.
Granatek CH, AW Cockerline 1978 Callus formation versus differentiation of cultured barley embryos: hormonal and osmotic interactions. In Vitro 14:212-217.

Hirate Y, H Araki, T Harada 1995 Image processing of asparagus chromosomes. Asparagus Res Newsletter 12:42-43.

Horsch RB, GE Jones 1980 A double filter paper technique for plating cultured plant cells. In Vitro 16:103-108.

Hsu JY, CC Yeh, TP Yang, WC Lin, HS Tsay 1990 Initiation of cell suspension cultures and plant regeneration from protoplast of asparagus. Acta Hortic 271:135-143.

Kong Y, CK Chin 1988 Culture of asparagus protoplasts on porous polypropylene membrane. Plant Cell Rep 7:67-69.

Kunitake H, M Mii 1990 Somatic embryogenesis and plant regeneration from protoplasts of asparagus (Asparagus officinalis L.). Plant Cell Rep 8:706-710.

Kunitake I 1995 Chromosome variation of somatic embryo-derived plants of haploid asparagus. Asparagus Res Newsletter 12:45-46.

Levi A, KC Sink 1990 Differential effects of sucrose, glucose and fructose during somatic embryogenesis in asparagus. J Plant Physiol 137:184-189.

1991 Somatic embryogenesis in asparagus: the role of explants and growth regulators. Plant Cell Rep 10:71-75.

1992 Asparagus somatic embryos: production in suspension culture and conversion to plantlets on solidified medium as influenced by carbohydrate regime. Plant Cell Tissue Organ Cult 31:115-122.

Lu C, V Vasil, IK Vasil 1983 Improved efficiency of somatic embryogenesis and plant regeneration in tissue cultures of maize (Zea mays L.). Theor Appl Genet 66:285-289. 
Magasanik B 1961 Catabolite repression. Cold Spring Harbor Symp Quant Biol 26:249-257.

Malnassy P, JH Ellison 1970 Asparagus tetraploids from callus tissue. Hortscience 5:444-445.

May RA, Sink KC 1995 Genotype and auxin influence direct somatic embryogenesis from protoplasts derived from embryogenic cell suspensions of Asparagus officinalis L. Plant Sci 108:71-84.

Morgan ER, GK Burge, JF Seelye, JE Grant, ME Hopping 1995 Interspecific hybridization between Limonium perigrinum and $\mathrm{Li}$ monium purpuratum. Euphytica 83:215-224.

Murashige T, F Skoog 1962 A revised medium for rapid growth and bioassays with tobacco tissue cultures. Physiol Plant 15:473497.

Odake Y, A Udagawa, H Saga, M Mii 1993 Somatic embryogenesis of tetraploid plants from internodal segments of a diploid cultivar of Asparagus officinalis L. grown in liquid culture. Plant Sci 94: 173-177.

Snedecor GW, WG Cochran 1969 Statistical methods. 6th ed. Iowa State University Press, Ames. 593 pp.

Tassi F, FM Restivo, PP Puglisi, G Cacco 1984 Effect of glucose on glutamate dehydrogenase and acid phosphatase and its reversal by cyclic adenosine 3': 5'-monophosphate in single cell cultures of Asparagus officinalis. Physiol Plant 60:61-64. 